\title{
FAKTOR-FAKTOR YANG BERHUBUNGAN DENGAN STATUS IMUNISASI LANJUTAN DIDESA SIDOHARJO PUSKESMAS PRINGSEWU
}

\section{FACTORS RELATED TO THE CONTINUOUS IMMUNIZATION STATUS IN THE SIDOHARJO VILLAGE PUSKESMAS PRINGSEWU}

\author{
Heni Retnawati ${ }^{1}$, Siti Rohani ${ }^{2,}$ Sucia Dwi Nugerahaeni ${ }^{3}$, Eka Tri Wulandari ${ }^{4}$ \\ ${ }^{1234}$ Fakultas Kesehatan Universitas Aisyah Pringsewu \\ e-mail : heniretnawati065@gmail.com
}

\begin{abstract}
Factors Related To The Continuous Immunization Status In The Sidoharjo Village Puskesmas Pringsewu. The coverage of Pentavalen boster immunization in Sidoharjo village in 2018 was $60.7 \%$ and the coverage of MR boster immunization was $67.1 \%$. Pre survey data of pentavalent immunization coverage of Sidoharjo Village is $72 \%$ and MR immunization coverage of MR is $65 \%$. Some factors that can cause the completeness of the immunization status are the mother's educational status, mother's knowledge, and the occupational status of the mother. The purpose of this study was to determine the frequency distribution and the percentage of each variable in the status of maternal education, maternal knowledge and occupation of the mother as well as the factors associated with the status of advanced immunization at the Posyandu Pekon Sidoharjo working area of the Pringsewu Community Health Center. This study used an observational analytic method with a cross sectional approach. The sample of 41 respondents were taken using a purposive sampling method. The results obtained by the distribution of frequencies and the percentage of maternal education level with 28 primary education levels $54,9 \%$, secondary education levels 16 people $31.4 \%$ and high education levels 7 people 13,7\%. Working mothers are 21 people 41, 2\% while unworking mothers are 30 people $58.8 \%$. Mothers with low knowledge of immunization 29 people $56.9 \%$ while mothers with high knowledge of immunization 22 people $43.1 \%$. Variables related to completeness of advanced immunization status are mother's knowledge ( $\mathrm{p}$ value 0,036 ), and mother's occupation ( $\mathrm{p}$ value 0,000 ). While the unrelated variable is the mother's educational status ( $\mathrm{p}$ value 0,112 ).
\end{abstract}

Keywords : Toddler, Immunization, education, knowledge. Profession

\begin{abstract}
Abstrak : Faktor-Faktor Yang Berhubungan Dengan Status Imunisasi Lanjutan Didesa Sidoharjo Puskesmas Pringsewu. Cakupan imunisasi boster Pentavalen desa Sidoharjo pada tahun 2018 sebesar 60,7\% dan cakupan imunisasi boster MR sebesar 67,1\%. Data pra survey cakupan imunisasi boster pentavalen Desa Sidoharjo sebesar $72 \%$ dan cakupan imunisasi bo ster MR sebesar $65 \%$. Beberapa faktor yang dapat menyebabkan status kelengkapan imunisasi tersebut adalah status pendidikan ibu, pengetahuan ibu, dan status pekerjaan ibu. Tujuan penelitian ini untuk mengetahui distribusi frekuensi dan presentase tiap variabel status Pendidikan ibu, pengetahuan ibu dan pekerjaan ibu serta faktor-faktor yang berhubungan dengan status imunisasi lanjutan pentavalen di Posyandu Pekon Sidoharjo wilayah kerja Puskesmas Pringsewu. Penelitian ini menggunakan metode analitik observasional dengan pendekatan cross sectional. Sampel penelitian sebanyak 41 responden menggunakan metode purposive sampling. Hasil penelitian diperoleh distribusi frekuensi dan presentase tingkat pendidikan ibu dengan tingkat pendidikan dasar 28 orang 54,9\%, tingkat pendidikan menengah 16 orang 31,4\% dan tingkat pendikan tinggi 7 orang $13,7 \%$. Ibu yang bekerja 21 orang 41,2\% sedangkan ibu tidak bekerja 30 orang 58,8 \%. Ibu dengan pengetahuan rendah terhadap imunisasi 29 orang 56,9\% sedangkan ibu dengan tpengetahuan tinggi terhadap imunisasi 22 orang 43,1\%. Variabel yang berhubungan dengan kelengkapan status imuniasi lanjutan yaitu pengetahuan ibu ( $\mathrm{p}$ value 0,036 ), dan pekerjaan ibu ( $\mathrm{p}$ value 0,000 ). Sementara variabel yang tidak berhubungan yaitu status pendidikan ibu ( $\mathrm{p}$ value $0,112)$.

Kata kunci : Ibu Balita, Imunisasi, pendidikan, pengetahuan. pekerjaan
\end{abstract}




\section{PENDAHULUAN}

Menurut Undang-Undang Nomor 36 Tahun 2009 tentang Kesehatan, imunisasi adalah bentuk kegiatan prioritas Kementerian Kesehatan RI untuk mencegah terjadinya penyakit menular. Imunisasi merupakan salah satu bentuk nyata komitmen pemerintah untuk mencapai Sustainable Development Goals (SDGs) khususnya untuk menurunkan angka kematian pada anak (Kementerian Kesehatan RI, 2017).

Imunisasi adalah suatu upaya pemberian kekebalan kepada seseorang secara aktif terhadap suatu penyakit. Seseorang yang mendapatkan imunisasi berarti telah diberikan kekebalan terhadap suatu penyakit tertentu, sehingga apabila suatu saat terpajan dengan penyakit tersebut tidak akan sakit atau hanya mengalami sakit ringan. Namun, anak kebal atau resisten terhadap suatu penyakit belum tentu kebal terhadap penyakit yang lainnya. Lebih dari 1,4 juta anak di dunia meninggal setiap tahunnya karena penyakit yang sebenarnya dapat dicegah dengan imunisasi (Kementerian Kesehatan RI, 2014).

Dalam Global Vaccine Action Plan tahun 2011-2020 yang dipublikasikan oleh World Health Organization (WHO), imunisasi dapat mencegah sekitar 2,5 juta kematian setiap tahunnya. Apabila individu mendapatkan imunisasi maka individu tersebut dapat terlindungi dari penyakit yang dapat dicegah dengan Imunisasi (PD3I) seperti tuberkulosis, difteri, pertusis, campak, polio, tetanus, hepatitis-B, serta pneumonia. Anak-anak yang telah diimunisasi memiliki kesempatan lebih baik untuk berkembang dan mewujudkan potensi mereka dan keuntungan tersebut semakin meningkat dengan melakukan imunisasi ulangan pada masa remaja dan dewasa. Imunisasi termasuk bagian dari paket komprehensif intervensi untuk pencegahan dan pengendalian penyakit, sehingga merupakan investasi untuk masa depan dunia (WHO, 2013).

Meskipun imunisasi secara luas dianggap sebagai alat yang efektif untuk menghentikan beban terkait PD3I, masih ada lebih dari 3 juta orang meninggal akibat PD3I tiap tahun nya dengan 1,5 juta diantaranya adalah anak-anak usia di bawah 5 tahun. Salah satu penelitian yang dilakukan di Etiopia mendapatkan hasil bahwa terdapat sekitar 26,3 juta anak dibawah usia satu tahun belum diimunisasi dengan vaksin Difteri-Pertusis-Tetanus (DPT) di tahun 2008 (Maleko A, 2017). Selain itu, pada tahun 2015 Indonesia memiliki 37\% kasus difteri yang penderitanya belum mendapatkan imunisasi DPT3 (Kementerian Kesehatan RI, 2015). Difteri merupakan contoh PD3I yang menyumbangkan angka morbiditas dan mortalitas yang cukup besar.

Indonesia telah menyelenggarakan program imunisasi sejak tahun 1956 yang diberikan kepada populasi yang dianggap rentan terjangkit penyakit menular, yaitu bayi, balita, anak-anak, wanita usia subur, dan ibu hamil. Program imunisasi telah terbukti paling efektif dan efisien dalam memberikan pelayanan kesehatan di Indonesia. Namun kenyataannya, masih banyak permasalahan yang timbul akibat kurangnya cakupan imunisasi di Indonesia (Kemenkes RI 2014).

Indonesia memiliki target imunisasi lanjutan Baduta sebesar 70\% pada tahun 2018, sedangkan cakupan imunisasi Pentavalen ((DPT-HB-HIB) Baduta tahun 2018 mencapai 61,3\% dan cakupan imunisasi boster MR mencapai 77,3\% (Riskesdas 2018). Untuk mencapai target nasional dan global dalam eradikasi, eliminasi, dan reduksi terhadap PD3I, cakupan imunisasi harus dipertahankan setinggi-tingginya dan merata sampai mencapai tingkat Population Immunity (kekebalan masyarakat) yang tinggi (Dinkes Prov Lampung 2015).

Imunisasi lanjutan masih menjadi hal yang sering dilupakan oleh masyarakat, faktanya imunisasi lanjutan bertujuan untuk melengkapi imunisasi dasar pada bayi sehingga dapat mempertahankan tingkat kekebalan atau memperpanjang masa perlindungan terhadap penyakit (Kementerian Kesehatan RI, 2017). 
Saat ini salah satu program pemerintah terbaru terkait pemberian imunisasi adalah penggunaan vaksin kombinasi yang dikenal sebagai Vaksin Pentavalen (DPT-HB-HIB). Vaksin ini merupakan gabungan vaksin DPT-HB ditambah Hib. Di Indonesia, pelaksanaan pemberian imunisasi DPT-HBHib baru dilaksanakan mulai tahun 2014, sehingga pencapaian cakupan imunisasi ini masih belum sesuai harapan (Ibrahim, 2016)

Angka kematian ibu di Indonesia tahun 2017 berjumlah 4167 per 100000 kelahiran hidup. Sedangkan angka kematian bayi di Indonesia pada tahun 2017 berjumlah 23972 per 100000 kelahiran ibu (Kemenkes 2018). Jumlah kasus difteri diIndonesia tersebar ke delapan belas propinsi termasuk propinsi Lampung. Cakupan Imunisasi Boster pentavalen (DPT-HB-HIB) Porpinsi Lampung sebesar 69,2\% dan cakupan imunisasi boster MR sebesar 74\% (Kemenkes 2018)

Target imunisasi tahun 2018 sebanyak 90\% data cakupan imunisasi Dinas Kesehatan Kabupaten Pringsewu tahun 2018 sebanyak 23\% Target imunisasi Dinas Kesehatan Kabupaten Pringsewu tahun 2019 sebanyak $95 \%$. Data pra survey cakupan imunisasi boster pentavalen (DPTHB-HIB) Dinas Kesehatan Kabupaten Pringsewu tahun 2019 sebanyak 28\% dan cakupan imunisasi boster MR sebesar 29,3 \% (Dinkes Kabupaten Pringsewu 2019). Cakupan imunisasi Puskesmas Pringsewu tahun 2018 sebesar 51,2\% data pra survey cakupan imunisasi boster pentavalen (DPTHB-HIB) Puskesmas Pringsewu tahun 2019 sebanyak 61,5\% dan cakupan imunisasi boster MR $46,7 \%$.

Desa Sidoharjo merupakan bagian dari wilayah Kerja Puskesma Pringsewu dan terdiri dari enam posyandu. Imunisasi lanjutan telah dilaksanakan di Desa Sidoharjo dengan sasaran Balita dengan usia 3 tahun sebanyak 41 balita. Sedangkan cakupan imunisasi boster Pentavalen (DPT-HBHIB) desa Sidoharjo pada tahun 2018 sebesar 60,7\% dan cakupan imunisasi boster MR sebesar 67,1 $\%$. Data pra survey cakupan imunisasi boster pentavalen (DPT-HB-HIB) Desa Sidoharjo sebesar $72 \%$ dan cakupan imunisasi boster MR sebesar $65 \%$.

Berdasarkan penelitian sebelumnya yang dilakukan oleh Nanda Salsabila Itsar yang berjudul Faktor-Faktor Yang Berhubungan Dengan Status Imunisasi Lanjutan Di Wilayah Kerja Puskesmas Labuhan Ratu Kota Bandar Lampung Tahun 2018 oleh Nanda Salsabila Itsa didapatkan hasil analisa yaitu $42,9 \%$ responden memiliki status imunisasi lanjutan lengkap dan 57,1\% tidak lengkap. Variabel yang berhubungan dengan kelengkapan status imuniasi lanjutan di wilayah kerja Puskesmas Labuhan Ratu Kota Bandar Lampung yaitu pengetahuan ibu ( $\mathrm{p}$ value 0,029), sikap ibu ( $\mathrm{p}$ value 0,022) dan pekerjaan ibu ( $\mathrm{p}$ value 0,014$)$. Sementara variabel yang tidak berhubungan yaitu status pendidikan ibu (pvalue 0,384), keterjangkauan tempat pelayanan kesehatan ( $\mathrm{p}$ value 0,344 ) dan peran petugas kesehatan ( $\mathrm{p}$ value 0,571 ).

Berdasarkan latar belakang tersebut penulis tertarik untuk meneliti faktor-faktor yang berhubungan dengan status imunisasi lanjutan di desa Sidoharjo wilayah kerja Puskesmas Pringsewu tahun 2019.

\section{METODE}

Jenis penelitian ini adalah penelitian kuantitatif adalah penelitian ilmiah yang sistematis terhadap bagian-bagian dan fenomena serta hubungan-hubungannya, dengan desain Analitik. Desain analitik adalah survei atau penelitian yang mencoba menggali bagaimana fenomena kesehatan itu terjadi.

Penelitian ini dilakukan di seluruh posyandu di des a $\mathrm{Sidoh}$ arjo wilayah kerja Puskesmas Pringsewu yaitu Posyandu merpati 1, Merpati 2, Merpati 3, Merpati 4, Merpati 5 dan Merpati 6. Penelitian dilaksanakan pada bulan Februari 2020.

https://ejournal.umpri.ac.id/index.php/JIK 3 
Populasi adalah keseluruhan Obyek penelitian atau Obyek yang diteliti (Prpf.Dr. Soekidjo Notoatmodjo, 2010). Populasi pada penelitian ini adalah ibu yang membawa bayi yang berumur 18 bulan sampai 3 tahun dan datang ke posyandu desa Sidoharjo wilayah kerja Puskesmas Pringsewu.

Peneliti menentukan jumlah sampel minimal yang dapat diambil dalam penelitian ini, adapun metode statistik yang digunakan untuk menentukan besar sampel adalah :

$$
\mathrm{n}=\frac{\mathrm{N}}{1+\mathrm{N}\left(\mathrm{d}^{2}\right)}
$$

Keterangan :

$\mathrm{N} \quad=$ Jumlah populasi

$\mathrm{n}=$ Besar Sampel

$\mathrm{d}=$ presisi mutlak (tingkat kesalahan); $10 \%=0,01$

(Notoatmodjo, 2012)

Berdasarkan rumus tersebut diatas, maka besarnya sampel penelitian yang digunakan dalam penelitian ini adalah sebagai berikut :

$$
\begin{aligned}
\mathrm{n} & =\frac{103}{1+103(0,1)^{2}} \\
& =\frac{103}{2.03}=50,7 \text { dibulatkan menjadi } 51 \text { responden }
\end{aligned}
$$

Penelitian ini menggunakan teknik pengambilan sampel purposive sampling yaitu dengan cara memilih sampel diantara populasi yang sesuai dengan kriteria inklusi dan eksklusi yang dikehendaki peneliti.

Sampel pada penelitian ini terdiri dari kriteria Inklusi dan kriteria esklusi. Kriteria inklusi adalah ciri-ciri yang perlu dipenuhi oleh setiap anggota populasi untuk diambil sebagai sampel, sedangkan kriteria ekslusi adalah ciri-ciri anggota populasi yang tidak dapat dimbil sebagai sampel (Notoatmodjo, 2012).

Kriteria inklusi pada penelitian ini yaitu:

1. Responden bersedia menjadi objek penelitian dan hadir saat pengambilan data.

2. Ibu yang memiliki anak usia 18 bulan sampai 3 tahun

3. Bayi lahir normal dan sehat.

4. Responden dapat membaca dan menulis.

5. Responden memiliki kartu KMS yang sudah terisi catatan imunisasi.

Sedangkan kriteria eksklusi dalam penelitian ini yaitu:

1. Ibu yang memiliki anak dengan kontraindikasi imunisasi seperti kelainan kongenital, imunodefisiensi, alergi/ hipersensitif terhadap vaksin, dan lain-lain.

Analisis univariat ini dilakukan terhadap tiap variabel dari hasil penelitian berupa distribusi frekuensi dan presentase tiap variabel pengetahuan ibu, pekerjaan ibu dan pendidikan ibu terhadap imunisasi lanjutan tahun 2019.

$$
\mathrm{P}=\frac{\mathrm{f}}{\mathrm{n}} \mathrm{x} 100
$$

Keterangan :

$\mathrm{P}=$ Persentase

$\mathrm{F}=$ jumlah responden yang menjawab benar

$\mathrm{N}=$ Jumlah sampel 
Analisis bivariat adalah analisis yang dilakukan terhadap dua variabel yang diduga berhubungan atau berkorelasi. Pada penelitian ini variabel yang menggunakan uji chi square adalah pengetahuan, Pendidikan dan pekerjaan ibu balita. Pengujian dilakukan dengan menggunakan bantuan program SPSS.

$$
X^{2}=\sum_{i}^{k}=1 \frac{\left(f_{o}-f_{h}\right)^{2}}{f_{h}}
$$

$\mathrm{X}^{2}=$ Chi Square

$\mathrm{f}_{\mathrm{o}}=$ frekuensi yang diobservasi

$\mathrm{f}_{\mathrm{h}}=$ frekuensi yang diharapkan

Untuk dapat membuat keputusan tentang hipotesis yang diajukan diterima atau ditolak, maka chi square $_{\text {hitung }}$ tersebut dibandingkan dengan chi square $_{\text {tabel }}$ dengan dk dan taraf kesalahan $5 \%$ dengan ketentuan apabila chi square hitung < chi square tabel, maka Ho diterima dan $\mathrm{Ha}$ ditolak, dan apabila chi square $_{\text {hitung }}>$ chi square $_{\text {tabel }}$ maka Ho ditolak dan Ha diterima (Sugiono, 2010). Untuk melihat kebermaknaan hubungan kedua variabel, maka dilihat dari p pada taraf signifikan $5 \%$.

\section{HASIL}

Analisis Univariat

1. Tingkat Pendidikan

Tabel 4.1 Distribusi Frekuensi Tingkat Pendidikan Ibu di Desa Sidoharjo Wilayah Kerja Puskesmas Pringsewu Tahun 2019

\begin{tabular}{ccc}
\hline $\begin{array}{c}\text { Tingkat } \\
\text { Pendidikan Ibu }\end{array}$ & Frekuensi & Persentase (\%) \\
\hline Dasar & 28 & $54,9 \%$ \\
Menengah & 16 & $31,4 \%$ \\
Tinggi & 7 & $13,7 \%$ \\
Jumlah & 51 & $100 \%$ \\
\hline
\end{tabular}

Berdasarkan tabel 4.1 diketahui bahwa dari 51 responden didapatkan sebanyak 28 orang $(54,9 \%)$ tingkat pendidikan dalam kategori dasar, 16 orang $(31,4 \%)$ tingkat pendidikan dalam kategori menengah dan sebanyak 7 orang $(13,7 \%)$ dalam kategori tinggi.

\section{Perkerjaan}

Tabel 4.2 Distribusi Frekuensi Pekerjaan Ibu di Desa Sidoharjo Wilayah Kerja Puskesmas Pringsewu Tahun 2019

\begin{tabular}{ccc} 
Pekerjaan Ibu & Frekuensi & Persentase $(\boldsymbol{\%})$ \\
\hline Tidak bekerja & 30 & $58,8 \%$ \\
Bekerja & 21 & $41,2 \%$ \\
\hline Jumlah & 51 & $100 \%$ \\
\hline
\end{tabular}

Berdasarkan tabel 4.2 diketahui bahwa dari 51 responden didapatkan sebanyak 30 responden $(58,8 \%)$ tidak bekerja dan sebanyak 21 responden $(41,2 \%)$ bekerja. 
Vol 10 No 1 Januari 2021 | Page 1-12

\section{Pengetahuan}

Tabel 4.3 Distribusi Frekuensi Tingkat Pengetahuan Tentang Imunisasi Lanjutan di Desa Sidoharjo Wilayah Kerja Puskesmas Pringsewu Tahun 2019

\begin{tabular}{ccc} 
Tingkat Pengetahuan & Frekuensi & Persentase $(\boldsymbol{\%})$ \\
\hline Rendah & 29 & $56,9 \%$ \\
Tinggi & 22 & $43,1 \%$ \\
\hline Jumlah & 51 & $100 \%$ \\
\hline
\end{tabular}

Berdasarkan tabel 4.3 diketahui bahwa dari 51 responden didapatkan sebanyak 29 responden $(56,9 \%)$ tingkat pengetahuannya rendah dan sebanyak 22 responden $(43,1 \%)$ tingkat pengetahuannya tinggi.

\section{Status Imunisasi Lanjutan}

Tabel 4.4 Distribusi Frekuensi Status Imunisasi Lanjutan di Desa Sidoharjo Wilayah Kerja Puskesmas Pringsewu Tahun 2019

\begin{tabular}{ccc}
\hline $\begin{array}{c}\text { Status Imunisasi } \\
\text { Lanjutan }\end{array}$ & Frekuensi & $\begin{array}{c}\text { Persentase } \\
(\boldsymbol{\%})\end{array}$ \\
\hline Tidak mendapatkan & 26 & $51,0 \%$ \\
Mendapatkan & 25 & $49,0 \%$ \\
\hline Jumlah & 51 & $100 \%$ \\
\hline
\end{tabular}

Berdasarkan tabel 4.4 diketahui bahwa dari 58 responden didapatkan sebanyak 26 responden (51\%) tidak mendapatkan imunisasi lanjutan dan sebanyak 25 responden (49\%) mendapatkan imunisasi lanjutan.

\section{Analisis Bivariat}

1. Hubungan Antara Pendidikan Ibu dengan Status Imunisasi Lanjutan Pada Anak

Tabel 4.5 Hubungan Antara Pendidikan Ibu dengan Status Imunisasi Lanjutan Pada Anak di Desa Sidoharjo Wilayah Kerja Puskesmas Pringsewu tahun 2019

\begin{tabular}{|c|c|c|c|c|c|c|c|}
\hline \multirow{3}{*}{ Pendidikan Ibu } & \multicolumn{4}{|c|}{ Status Imunisasi Lanjutan } & \multicolumn{2}{|c|}{ Total } & \multirow{3}{*}{ P Value } \\
\hline & \multicolumn{2}{|c|}{$\begin{array}{c}\text { Tidak } \\
\text { Mendapatkan }\end{array}$} & \multicolumn{2}{|c|}{ Mendapatkan } & \multirow{2}{*}{$\mathbf{N}$} & \multirow{2}{*}{$\%$} & \\
\hline & $\mathrm{N}$ & $\%$ & $\mathrm{~N}$ & $\%$ & & & \\
\hline Dasar & 16 & 57,1 & 12 & 42,9 & 28 & 100 & \multirow{4}{*}{0,112} \\
\hline Menengah & 9 & 56,2 & 7 & 43,8 & 16 & 100 & \\
\hline Tinggi & 1 & 14,3 & 6 & 85,7 & 7 & 100 & \\
\hline Jumlah & 26 & 51,0 & 25 & 49,0 & 51 & 100 & \\
\hline
\end{tabular}

Berdasarkan tabel 4.5 diketahui bahwa dari 28 responden berpendidikan dasar didapatkan 16 responden $(57,1 \%)$ tidak mendapatkan imunisasi lanjutan dan sebanyak 12 responden $(42,9 \%)$ mendapatkan imunisasi lanjutan. Dari 16 responden berpendidikan menengah didapatkan 9 responden $(56,2 \%)$ tidak mendapatkan imunisasi lanjutan dan sebanyak 7 responden $(43,8 \%)$ mendapatkan imunisasi lanjutan. Sedangkan dari 7 responden berpendidikan tinggi didapatkan 1 responden $(14,3 \%)$ tidak mendapatkan imunisasi lanjutan dan sebanyak 6 responden $(85,7 \%)$ mendapatkan imunisasi lanjutan. Hasil uji statistik dengan menggunakan uji chi-square didapatkan nilai p-value 0,112 dan $\geq$ nilai alpha $(\alpha>0,05)$, maka disimpulkan tidak ada hubungan tingkat pendidikan ibu dengan status imunisasi lanjutan pada anak di Desa Sidoharjo wilayah kerja Puskesmas Pringsewu tahun 2019. 
Vol 10 No 1 Januari 2021 | Page 1-12

2. Hubungan Antara Pekerjaan Ibu dengan Status Imunisasi Lanjutan Pada Anak Tabel 4.6 Hubungan Antara Pekerjaan Ibu dengan Status Imunisasi Lanjutan Pada Anak di Desa Sidoharjo Wilayah Kerja Puskesmas Pringsewu Tahun 2019

\begin{tabular}{|c|c|c|c|c|c|c|c|c|}
\hline \multirow{3}{*}{ Pekerjaan Ibu } & \multicolumn{4}{|c|}{ Status Imunisasi Lanjutan } & \multicolumn{2}{|c|}{ Total } & \multirow{3}{*}{ P Value } & \multirow{3}{*}{$\begin{array}{c}\text { OR } \\
(95 \% \mathrm{CI})\end{array}$} \\
\hline & \multicolumn{2}{|c|}{ Tidak Mendapatkan } & \multicolumn{2}{|c|}{ Mendapatkan } & \multirow{2}{*}{$\mathbf{N}$} & \multirow{2}{*}{$\%$} & & \\
\hline & $\mathrm{N}$ & $\%$ & $\mathrm{~N}$ & $\%$ & & & & \\
\hline Bekerja & 18 & 85,7 & 3 & 14,3 & 21 & 100 & \multirow{3}{*}{0,000} & \multirow{3}{*}{$\begin{array}{c}16,500 \\
3,810-71,4658\end{array}$} \\
\hline Tidak Bekerja & 8 & 26,7 & 22 & 73,3 & 30 & 100 & & \\
\hline Jumlah & 26 & 51,0 & 25 & 48,0 & 51 & 100 & & \\
\hline
\end{tabular}

Berdasarkan tabel 4.6 diketahui bahwa dari 21 responden bekerja didapatkan 18 responden $(85,7 \%)$ tidak mendapatkan imunisasi lanjutan dan sebanyak 3 responden $(14,3 \%)$ mendapatkan imunisasi lanjutan. Sedangkan dari 30 responden tidak bekerja didapatkan 8 responden $(26,7 \%)$ tidak mendapatkan imunisasi lanjutan dan sebanyak 22 responden $(73,3 \%)$ mendapatkan imunisasi lanjutan. Hasil uji statistik dengan menggunakan uji chi-square didapatkan nilai p-value 0,000 nilai $\alpha<0,05$, maka disimpulkan hubungan antara pekerjaan ibu dengan status imunisasi lanjutan pada anak di Desa Sidoharjo wilayah kerja Puskesmas Pringsewu tahun 2019. Hasil analisis didapatkan nilai OR = 16,500 yang artinya ibu yang tidak bekerja berpeluang 16,500 kali mendapatkan imunusasi lanjutan dibandingkan ibu yang bekerja.

3. Hubungan Antara Pengetahuan Imunisasi Ibu Terhadap Status Imunisasi Lanjutan Pada Anak

Tabel 4.7 Hubungan Antara Pengetahuan Imunisasi Ibu Terhadap Status Imunisasi Lanjutan Pada Anak di Desa Sidoharjo Wilayah Kerja Puskesmas Pringsewu Tahun 2019

\begin{tabular}{|c|c|c|c|c|c|c|c|c|}
\hline \multirow{3}{*}{ Pengeta huan Ibu } & \multicolumn{4}{|c|}{ Status Imunisasi Lanjutan } & \multicolumn{2}{|c|}{ Total } & \multirow{3}{*}{ P Value } & \multirow{3}{*}{$\begin{array}{c}\text { OR } \\
(95 \% \mathrm{CI})\end{array}$} \\
\hline & \multicolumn{2}{|c|}{ Tidak Mendapatkan } & \multicolumn{2}{|c|}{ Mendapatkan } & \multirow{2}{*}{$\mathbf{N}$} & \multirow{2}{*}{$\%$} & & \\
\hline & $\mathrm{N}$ & $\%$ & $\mathrm{~N}$ & $\%$ & & & & \\
\hline Rendah & 19 & 65,5 & 10 & 34,5 & 29 & 100 & \multirow{3}{*}{0,036} & \multirow{3}{*}{$\begin{array}{c}4,071 \\
1,252- \\
13,243\end{array}$} \\
\hline Tinggi & 7 & 31,8 & 15 & 68,2 & 22 & 100 & & \\
\hline Jumlah & 21 & 51,0 & 20 & 48,0 & 51 & 100 & & \\
\hline
\end{tabular}

Berdasarkan tabel 4.7 diketahui bahwa dari 29 responden berpengetahuan rendah didapatkan 19 responden $(65,5 \%)$ tidak mendapatkan imunisasi lanjutan dan sebanyak 10 responden $(34,5 \%)$ mendapatkan imunisasi lanjutan. Sedangkan dari 22 responden berpengetahuan tinggi didapatkan 7 responden (31,8\%) tidak mendapatkan imunisasi lanjutan dan sebanyak 15 responden $(68,2 \%)$ mendapatkan imunisasi lanjutan. Hasil uji statistik dengan menggunakan uji chi-square didapatkan nilai p-value 0,036 nilai $\alpha<0,05$, maka disimpulkan hubungan antara pengetahuan imunisasi ibu terhadap status imunisasi lanjutan pada anak di Desa Sidoharjo wilayah kerja Puskesmas Pringsewu tahun 2019. Hasil analisis didapatkan nilai $\mathrm{OR}=4,071$ yang artinya ibu yang berpengetahuan tinggi berpeluang 4,071 kali mendapatkan imunusasi lanjutan dibandingkan ibu yang berpengetahuan rendah 


\section{PEMBAHASAN}

Univariat

1. Tingkat Pendidikan

Berdasarkan tabel 4.1 diketahui bahwa dari 51 responden didapatkan sebanyak 28 orang $(54,9 \%)$ tingkat pendidikan dalam kategori dasar, 16 orang $(31,4 \%)$ tingkat pendidikan dalam kategori menengah dan sebanyak 7 orang $(13,7 \%)$ dalam kategori tinggi

Pendidikan adalah proses seseorang mengembangkan kemampuan, sikap, dan bentukbentuk tingkah laku manusia di dalam masyarakat tempat ia hidup, proses sosial, yakni orang dihadapkan pada pengaruh lingkungan yang terpilih dan terkontrol (khususnya yang datang dari sekolah), sehingga dia dapat memperoleh atau mengalami perkembangan kemampuan sosial, dan kemampuan individu yang optimal (Istriyati, 2011).

Wanita sangat berperan dalam pendidikan di dalam rumah tangga. Mereka menanamkan kebiasaan dan menjadi panutan bagi generasi yang akan datang tentang perlakuan terhadap lingkungannya. Dengan demikian, wanita ikut menentukan kualitas lingkungan hidup ini. Untuk dapat melaksanakan pendidikan ini dengan baik, para wanita juga perlu berpendidikan baik formal maupun tidak formal. Akan tetapi pada kenyataan taraf, pendidikan wanita masih jauh lebih rendah daripada kaum pria. Seseorang ibu dapat memelihara dan mendidik anaknya dengan baik apabila ia sendiri berpendidikan (Juli Soemirat Slamet, 2000).

Kategori pendidikan dibagi menjadi tiga yaitu pendidikan dasar (SD-SMP), pendidikan menengah (SMA), dan Pendidikan tinggi (perguruan tinggi) (Anshory dkk, 2018). Sedangkan menurut Ramlan Surbakti, pengetahuan masyarakat terhadap proses partisipasi akan menentukan corak dan arah suatu keputusan yang akan diambil.

Menurut penelitian yang telah dilakukan sebelumnya menyatakan bahwa dari 30 responden pada status imunisasi tidak lengkap, 23 responden $(38,3 \%)$ memiliki tingkat pendidikan dasar dan yang memiliki tingkat pendidikan lanjut sebanyak 7 responden (11,7\%). Dari 30 responden pada status imunisasi lengkap, 13 responden $(21,7 \%)$ memiliki tingkat pendidikan dasar dan 17 responden $(28,3 \%)$ memiliki tingkat pendidikan lanjut (Istriyati, 2011).

\section{Perkerjaan}

Berdasarkan tabel 4.2 diketahui bahwa dari 51 responden didapatkan sebanyak 30 responden $(58,8 \%)$ tidak bekerja dan sebanyak 21 responden $(41,2 \%)$ bekerja. Dalam Kamus Besar Bahasa Indonesia bekerja adalah melakukan kegiatan/pekerjaan paling sedikit satu jam berturut-turut selama seminggu yang lalu dengan maksud untuk memperoleh atau membantu memperoleh pendapatan atau keuntungan. Sedangkan dalam kamus ekonomi bekerja adalah Kegiatan ekonomi yang dilakukan oleh seseorang dengan maksud memperoleh atau membantu memperoleh pendapatan atau keuntungan, lamanya bekerja paling sedikit 1 jam secara terusmenerus dalam seminggu yang lalu (termasuk pekerja keluarga tanpa upah yang membantu dalam suatu usaha/kegiatan ekonomi)

Salah satu penelitian mengatakan bahwa didapatkan kelompok imunisasi tidak lengkap sebanyak $26,2 \%$ bekerja, dan $23,8 \%$ tidak bekerja. Sedangkan pada kelompok imunisasi lengkap sebanyak $14,3 \%$ orang bekerja dan $35,7 \%$ orang tidak bekerja (Prihanti dkk, 2016). Hal ini didukung oleh penelitian lainnya yang mengatakan bahwa ibu dengan pekerjaan informal (IRT) atau tidak bekerja dapat fleksibel terkait waktu dibandingkan ibu yang memiliki pekerjaan formal (pada suatu instansi). Artinya pekerjaan formal memberikan efek negatif kepada responden untuk mengimunisasikan anaknya secara lengkap, sebaliknya pekerjaan informal memberikan efek positif kepada responden untuk mengimunisasi anaknya secara lengkap (Makamban \& Salmah, 2014). 


\section{Pengetahuan}

Berdasarkan tabel 4.3 diketahui bahwa dari 51 responden didapatkan sebanyak 29 responden $(56,9 \%)$ dengan tingkat pengetahuan rendah dan sebanyak 22 responden $(43,1 \%)$ dengan tingkat pengetahuan tinggi. Pengetahuan dapat diartikan sebagai informasi yang ditemui dan diperoleh oleh manusia dengan pengamatan akal untuk mengenali suatu benda atau kejadian yang sebelumnya belum pernah dilihat atau dirasakan. Pengetahuan sering dijadikan sebagai pedoman untuk mengetahui tingkat kecerdasan seseorang. Dalam Kamus Besar Bahasa Indonesia, pengetahuan diartikan sebagai segala sesuatu yang diketahui yang berkenaan dengan hal (mata pelajaran) (Notoatmodjo, 2010).

Pengetahuan dapat dikategorikan menjadi (1) Tinggi, jika subjek dapat menjawab $60 \%$ dari seluruh pertanyaan yang diberikan dengan benar, (0) Rendah, jika subjek menjawab $<60 \%$ pertanyaan dengan benar (Istriyati, 2011)

Penelitian yang dilakukan oleh Makamban et al (2014) didapatkan bahwa responden yang mengimunisasi anaknya dengan lengkap adalah ibu yang memiliki pengetahuan cukup lebih tinggi $(93,3 \%)$ dibandingkan ibu dengan pengetahuan kurang (73,8\%). Astriani (2016) juga menyatakan bahwa tingkat pengetahuan memiliki hubungan yang bermakna dengan kelengkapan imunisasi lanjutan di Puskesmas Denpasar Selatan Tahun 2016. Hal ini menunjukkan bahwa pengetahuan berperan penting terhadap pemberian imunisasi lanjutan pada anak (Makamban dkk, 2014).

\section{Status Imunisasi Lanjutan}

Berdasarkan tabel 4.4 diketahui bahwa dari 51 responden didapatkan sebanyak 26 responden $(51 \%)$ tidak mendapatkan imunisasi lanjutan dan sebanyak 25 responden (49\%) mendapatkan imunisasi lanjutan. Berdasarkan pasal 7 ayat 1 Peraturan Menteri Kesehatan Republik Indonesia Nomor 12 Tahun 2017 Tentang Penyelenggaraan Imunisasi, imunisasi lanjutan adalah ulangan imunisasi dasar untuk memperpanjang masa perlindungan atau mempertahankan tingkat kekebalan anak yang sudah mendapatkan imunisasi dasar. Sasaran imunisasi lanjutan diberikan pada anak usia dibawah dua tahun, anak usia sekolah dasar, dan Wanita Usia Subur (WUS). Imunisasi lanjutan yang diberikan untuk anak usia dibawah dua tahun yaitu difteri, pertusis, tetanus, hepatitis B, pneumonia, meningitis dan campak. Imunisasi lanjutan untuk anak usia sekolah dasar diberikan pada Bulan Imunisasi Anak Sekolah (BIAS) yaitu imunisasi campak, DT, dan Td. Imunisasi lanjutan pada WUS diberikan imunisasi terhadap penyakit tetanus dan difteri (Kementerian Kesehatan RI, 2017).

\section{Bivariat}

\section{Hubungan Antara Pendidikan Ibu dengan Status Imunisasi Lanjutan Pada Anak}

Berdasarkan hasil penelitian menunjukkan tidak ada hubungan antara tingkat pendidikan ibu dengan kelengkapan imunisasi lanjutan pada bayi di Desa Sdoharjo Kecamatan Pringsewu Kabupaten Pringsewu

Hal ini didasari dari hasil uji statistik dengan menggunakan uji chi-square didapatkan nilai p-value 0,112 nilai $\alpha>0,05$, maka disimpulkan tidak ada hubungan tingkat pendidikan ibu dengan status imunisasi lanjutan pada anak di Desa Sidoharjo wilayah kerja Puskesmas Pringsewu tahun 2019.

Tidak adanya hubungan Pendidikan ibu dengan tingkat imunisasi lanjutan didasari oleh pemahaman ibu atau pengetahuan ibu terhadap imunisasi sangat dipengaruhi oleh tingkat pendidikan ibu. Pendidikan seseorang merupakan salah satu proses perubahan tingkah laku, semakin tinggi Pendidikan seseorang maka akan semakin mempertibangkan dalam memilih tempat - tempat pelayanan kesehatan (Tawi, 2008). Dengan demikian sangat dimungkinkan 
ibuyang mempunyai Pendidikan tinggi akan memberikan imunisasi ditempat-tempat dengan pelayanan yang lebih lengkap. Dalam beberapa penelitian mengemukakan bahwa pendidikan ibu memiliki pengaruh penting bagi kesehatan anak - anaknya diantaranya adalah menyediakan lingkungan yang lebih baik dan penghasilan yang cukup (Chen, 2006).

Penelitian yang dilakukan oleh Makamban et al (2014) didapatkan bahwa responden yang mengimunisasi anaknya dengan lengkap adalah ibu yang memiliki pengetahuan cukup lebih tinggi (93,3\%) dibandingkan ibu dengan pengetahuan kurang $(73,8 \%)$.

Berdasarkan penelitian sebelumnya yang dilakukan oleh Nanda Salsabila Itsar yang berjudul Faktor-Faktor Yang Berhubungan Dengan Status Imunisasi Lanjutan Di Wilayah Kerja Puskesmas Labuhan Ratu Kota Bandar Lampung Tahun 2018 oleh Nanda Salsabila Itsa didapatkan hasil analisa yaitu 42,9\% responden memiliki status imunisasi lanjutan lengkap dan 57,1\% tidak lengkap. Variabel yang berhubungan dengan kelengkapan status imuniasi lanjutan di wilayah kerja Puskesmas Labuhan Ratu Kota Bandar Lampung yaitu pengetahuan ibu (p value 0,029), sikap ibu ( $\mathrm{p}$ value 0,022 ) dan pekerjaan ibu ( $\mathrm{p}$ value 0,014$)$. Sementara variabel yang tidak berhubungan yaitu status pendidikan ibu ( $\mathrm{p}$ value 0,384 ), keterjangkauan tempat pelayanan kesehatan ( $\mathrm{p}$ value 0,344 ) dan peran petugas kesehatan ( $\mathrm{p}$ value 0,571 ).

\section{Hubungan Antara Pekerjaan Ibu dengan Status Imunisasi Lanjutan Pada Anak}

Berdasarkan hasil penelitian menunjukkan ada hubungan antara tingkatan pekerjaan ibu dengan kelengkapan imunisasi lanjutan pada bayi di Desa Sdoharjo Kecamatan Pringsewu Kabupaten Pringsewu. Hal ini berdasarkan hasil uji statistik dengan menggunakan uji chi-square didapatkan nilai $\mathrm{p}$-value 0,000 nilai $\alpha<0,05$, maka disimpulkan hubungan antara pekerjaan ibu dengan status imunisasi lanjutan pada anak di Desa Sidoharjo wilayah kerja Puskesmas Pringsewu tahun 2019. Hasil analisis didapatkan nilai OR $=16,500$ yang artinya ibu yang tidak bekerja berpeluang 16,500 kali mendapatkan imunusasi lanjutan dibandingkan ibu yang bekerja

Hubungan antara pekerjaan ibu dengan kelengkapan imunisasi dasar bayi adalah jika ibu bekerja untuk mencari nafkah maka akan berkurang kesempatan waktu dan perhatian untuk membawa bayinya ke tempat pelayanan imunisasi, sehingga akan mengakibatkan bayinya tidak mendapatkan imunisasi (Sulfiati, 2014)

Berdasarkan penelitian sebelumnya yang dilakukan oleh Nanda Salsabila Itsar yang berjudul Faktor-Faktor Yang Berhubungan Dengan Status Imunisasi Lanjutan Di Wilayah Kerja Puskesmas Labuhan Ratu Kota Bandar Lampung Tahun 2018 oleh Nanda Salsabila Itsa didapatkan hasil analisa yaitu $42,9 \%$ responden memiliki status imunisasi lanjutan lengkap dan $57,1 \%$ tidak lengkap. Variabel yang berhubungan dengan kelengkapan status imuniasi lanjutan di wilayah kerja Puskesmas Labuhan Ratu Kota Bandar Lampung yaitu pengetahuan ibu ( $\mathrm{p}$ value 0,029), sikap ibu (p value 0,022) dan pekerjaan ibu ( $\mathrm{p}$ value 0,014$)$. Sementara variabel yang tidak berhubungan yaitu status pendidikan ibu ( $\mathrm{p}$ value 0,384 ), keterjangkauan tempat pelayanan kesehatan ( $\mathrm{p}$ value 0,344$)$ dan peran petugas kesehatan ( $\mathrm{p}$ value 0,571

\section{Hubungan Antara Pengetahuan Imunisasi Ibu Terhadap Status Imunisasi Lanjutan Pada Anak}

Berdasarkan hasil penelitian menunjukkan ada ibu bekerja lebih sedikit dari pada responden ibu yang tidak bekerja. Responden ibu dengan pengetahuan rendah terhadap imunisasi berjumlah 29 orang dengan presentase 56,9\% sedangkan responden dengan tingkat pengetahuan tinggi terhadap imunisasi berjumlah 22 orang dengan presentase 43,1\%.dari jumlah tersebut diketahui bahwa responden dengan tingkat pengetahuan rendah terhadap imunisasi lebih banyak dari pada responden dengan tingkat pengetahuan tinggi terhadap imunisasi. Berdasrkan data dan analisa

https://ejournal.umpri.ac.id/index.php/JIK $\mid \mathbf{1 0}$ 
pada bab sebelumnya didapatkan hasil nilai p-value 0,112 nilai $\alpha>0,05$ dengan demikian disimpulkan bahwa tidak terdapat hubungan antara pendidikan ibu dengan status imunisasi lanjutan pentavalen di desa Sidoharjo wilayah kerja Puskesmas Pringsewu tahun 2019. Berdasrkan data dan analisa pada bab sebelumnya didapatkan hasil nilai $\mathrm{p}$ value sebesar 0,00 nilai $\alpha<0,05$ dari data tersebut dapat disimpulkan bahwa terdapat hubungan antara pekerjaan ibu dengan status imunisasi lanjutan pentavalen di desa Sidoharjo wilayah kerja Puskesmas Pringsewu tahun 2019. Berdasrkan data dan analisa pada bab sebelumnya didapatkan hasil nilai $\mathrm{p}$ value sebesar 0,036 nilai $\alpha<0,05$ dari data tersebut dapat disimpulkan bahwa terdapat hubungan antara pengetahuan ibu terhadap status imunisasi lanjutan pentavalen di desa Sidoharjo wilayah kerja Puskesmas Pringsewu tahun 2019.

\section{SARAN}

Dari hasil penelitian, pengamatan dan analisis yang telah dilakukan maka peneliti memberikan saran Bagi Institusi Pendidikan (Universitas Aisyah Pringsewu) dapat meningkatkan fasilitas perpustakaan dengan menyediakan buku-buku referensi terbaru. Bagi Puskesmas Pringsewu dapat menyediakan papan informasi pelaksanaan imunsasi, mengintensifkan penyuluhan tentang imunisasi bekerjasama dengan kader dan aparat desa untuk meningkatkan pengetahuan masyarakat pentingnya imunisasi, jadwal posyandu dilaksanankan pada sore hari untuk memberikan kesempatan bagi ibu yang bekerja dan Bagi Responden dapat aktif dalam kegiatan posyandu, sadari pentingnya imunisasi bagi anak.

\section{DAFTAR PUSTAKA}

Anoraga. (2014). Psikologi Kerja. Jakarta: Rineka Cipta

Arikunto. (2010). Prosedur Penelitian Suatu Pendekatan Praktek. Jakarta: Rineka Cipta.

Anshory dkk. (2018). Pengantar Pendidikan. Malang: Universitas Muhammadiyah Malang

Dinkes Kab Pringsewu. (2018). Target dan Cakupan Imunisasi Lanjutan Pentavalen (DPT-HB-HIB)

Dinkes Kab Pringsewu. (2019). Target dan Data Imunisasi.

Fanni Pradila Rahma, dkk. (2019). Analisis Pelaksanaan Program Imunisasi Dpt- Hb- Hib Pentavalen Booster Pada Baduta Di Puskesmas Kota Semarang (Studi Kasus Pada Puskesmas Halmahera): https://ejournal3.undip.ac.id/index.php/jkm/article/view/22845. 10 November 2019

Hadianti, Dian Nur. (2014). Buku Ajar Imunisasi. Jakarta: Pusat Pendidikan dan Pelatihan Tenaga Kesehatan

Hadinegara, Sri Rejeki. (2011). Buku Satgas Imunisasi. Jakarta: IDAI.

Hadinegara, Sri Rejeki. (2014). Buku Satgas Imunisasi. Jakarta: IDAI.

Hardono, dkk. (2019). Pedoman Penulisan Tugas Akhir Mahasiswa. Lampung: Universitas Aisyah Pringsewu

Hastono dkk. (2011). Statistik Kesehatan. Jakarta: Rajawali Pers

Hastono, Sutanto Priyo. (2016). Analisis Data Kesehatan. Jakarta: Univrsitas Indonesia

https://ejournal.umpri.ac.id/index.php/JIK $\mid 11$ 
Itsa, Salsabila Nanda. (2019). Faktor-Faktor Yang Berhubungan Dengan Status Imunisasi Lanjutan Pentavalen (Dpt-Hb-Hib) Di Wilayah Kerja Puskesmas Labuhan Ratu Kota Bandar Lampung Tahun 2018. Fakultas Kedokteran Universitas Lampung: http://digilib.unila.ac.id/55361/. 27 Oktober 2019

Kartasasmita dkk. (2017). Petunjuk Teknis Kampanye dan Introduksi Imunisasi Measles Rubella $(M R)$. Jakarta: Kemenkes

Ningrum, Puspita. (2015). Hubungan Tingkat Pengetahuan Dengan Kepatuhan Ibu Dalam Pemberian Imunisasi Pentavalen Di Wilayah Kerja UPTD Puskesmas Gilingan Surakarta. Program Studi S 1 Keperawatan STIKES Kusuma Husada Surakarta. 16 Oktober 2019

Notoatmodjo, Soekidjo. (2010). Metodologi Penelitian Kesehatan. Jakarta: Rineka Cipta

Permatasari, Romadhona. (2010). Hubungan Tingkat Pendidikan Formal Ibu Terhadap Kelengkapan Imunisasi Pada Anak Usia 2 Tahun Di Kelurahan Semanggi Surakarta. Fakultas Kedokteran Universitas Muhammadiyah Surakarta: http://eprints.ums.ac.id/9309/. 20 November 2019

Pritasari, Kirana. (2018). Peran Rumah Sakit Dalam Rangka Menurunkan AKI dan AKA. Jakarta: KEMENKES

Puskesmas Pringsewu. (2018). Target dan Cakupan Imunisasi Lanjutan Pentavalen (DPT-HB-HIB) dan Data Cakupan Cakupan Imunisasi Lanjutan Pentavalen (DPT-HB-HIB) Sidoharjo

Puskesmas Pringsewu. (2019). Data Imunisasi

Riskesdas 2018. Hasil Utama Riskedas 2018. Litbangkes Depkes RI

Saputri, N. (2019). Modul Asuhan Neonatus, Bayi, Balita dan Anak Prasekolah. Yogyakarta: Pustaka Pranala

Sugoyono. 2016. Metode Penelitian. Bandung: Alfabeta CV

Sulfiati. (2010). Hubungan Tingkat Pendidikan, Pengetahuan dan Sikap Ibu Terhadap Pemeberian Imunisasi Dasar di Puskesmas Kassi-Kassi Makasar Tahun 2010. Laporan D3 thesis. Universitas Islam Negeri Alauddin Makassar: http://repositori.uin-alauddin.ac.id/3677/

Yulizar, dkk. (2017). Perilaku Ibu Dalam Pemberian Imunisasi Dpt/Hb-Hib Di Desa Sinabang Kecamatan Simeulue Timur. Institut Kesehatan Halvetia Medan. http:/ / ejournal.helvetia.ac.id/index.php/jkg. 10 November 2019 